NATIONAL LABORATORY

MANAGED BY UT-BATTELLE

FOR THE DEPARTMENT OF ENERGY

\title{
Ways to Minimize Water Usage in Engineered Geothermal Systems
}

\section{September 2012}

\section{Prepared by}

Joanna McFarlane, Kevin J. Qualls, A. Lou Qualls, Adrian S. Sabau, Hebi Yin, Lawrence M. Anovitz, Andrew K. Kercher, and Steven A. Wright

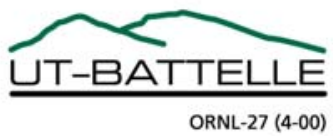




\section{DOCUMENT AVAILABILITY}

Reports produced after January 1, 1996, are generally available free via the U.S. Department of Energy (DOE) Information Bridge.

Web site http://www.osti.gov/bridge

Reports produced before January 1, 1996, may be purchased by members of the public from the following source.

National Technical Information Service

5285 Port Royal Road

Springfield, VA 22161

Telephone 703-605-6000 (1-800-553-6847)

TDD 703-487-4639

Fax 703-605-6900

E-mail info@ntis.gov

Web site http://www.ntis.gov/support/ordernowabout.htm

Reports are available to DOE employees, DOE contractors, Energy Technology Data Exchange (ETDE) representatives, and International Nuclear Information System (INIS) representatives from the following source.

Office of Scientific and Technical Information

P.O. Box 62

Oak Ridge, TN 37831

Telephone 865-576-8401

Fax 865-576-5728

E-mail reports@osti.gov

Web site http://www.osti.gov/contact.html

This report was prepared as an account of work sponsored by an agency of the United States Government. Neither the United States Government nor any agency thereof, nor any of their employees, makes any warranty, express or implied, or assumes any legal liability or responsibility for the accuracy, completeness, or usefulness of any information, apparatus, product, or process disclosed, or represents that its use would not infringe privately owned rights. Reference herein to any specific commercial product, process, or service by trade name, trademark, manufacturer, or otherwise, does not necessarily constitute or imply its endorsement, recommendation, or favoring by the United States Government or any agency thereof. The views and opinions of authors expressed herein do not necessarily state or reflect those of the United States Government or any agency thereof. 
Energy and Transportation Science Division

\title{
WAYS TO MINIMIZE WATER USAGE IN ENGINEERED GEOTHERMAL SYSTEMS
}

\author{
Authors \\ Joanna McFarlane \\ Kevin J. Qualls \\ A. Lou Qualls \\ Adrian S. Sabau \\ Hebi Yin \\ Lawrence M. Anovitz \\ Andrew K. Kercher \\ Steven A. Wright, Sandia National Laboratory
}

Date Published: September 2012

Prepared by

OAK RIDGE NATIONAL LABORATORY

Oak Ridge, Tennessee 37831-6283

managed by

UT-BATTELLE, LLC

for the

U.S. DEPARTMENT OF ENERGY

under contract DE-AC05-00OR22725 



\section{CONTENTS}

Page

LIST OF FIGURES

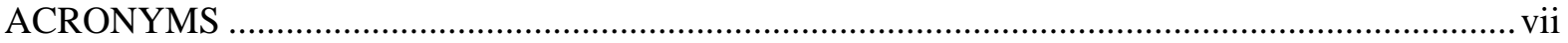

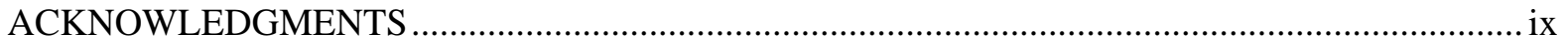

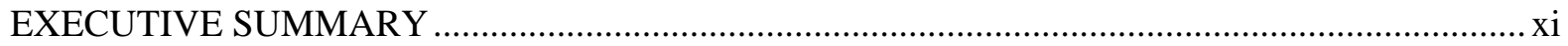

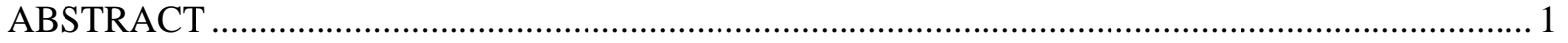

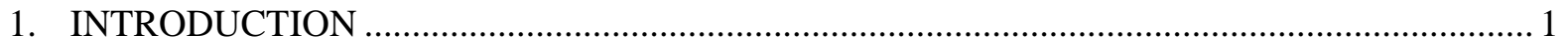

2. COMPUTED TOMOGRAPHIC SCANNING AS A TOOL TO CHARACTERIZE ROCK

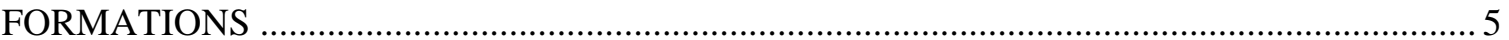

3. POROSITY MEASUREMENTS USING SCANNING TOMOGRAPHY …............................ 7

4. AIR COOLING VERSUS WATER COOLING IN BINARY POWER CYCLES ...................... 13 4.1 CONCEPTUAL DESIGN OF SUPERCRITICAL $\mathrm{CO}_{2}$ SYSTEM COUPLED WITH

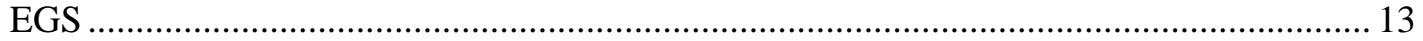

4.2 EXPERIMENTAL VALIDATION OF GEOTHERMAL LOOP PERFORMANCE ......... 14

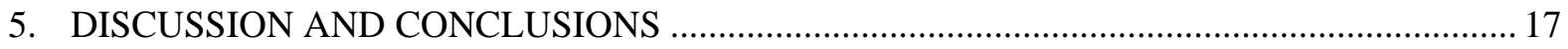

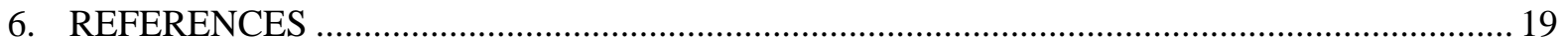





\section{LIST OF FIGURES}

Figure

Page

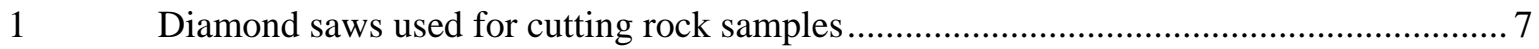

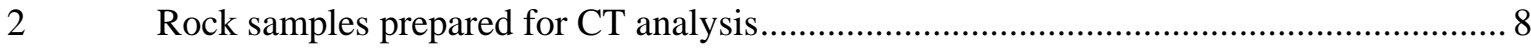

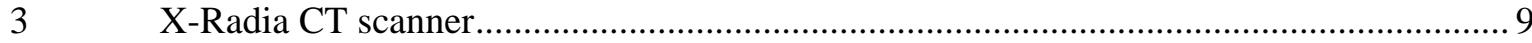

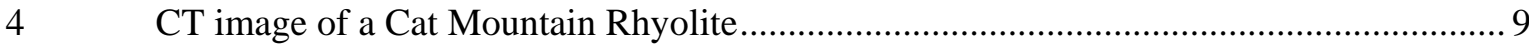

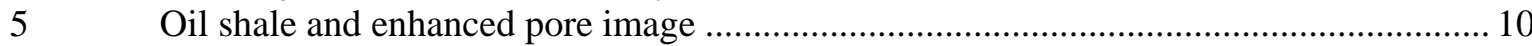

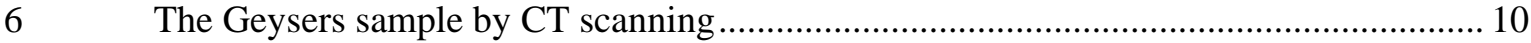

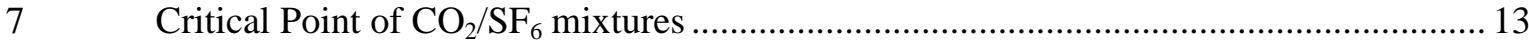

$8 \quad$ Rankine cycle showing the changes in the working fluid............................................ 14

9 Critical temperature as a function of $\mathrm{CO}_{2}$ mole fraction for $\mathrm{CO}_{2} / n$ butane mixtures ........ 15 



\section{ACRONYMS}

$\begin{array}{ll}\text { CCD } & \text { Charge Coupled Detector } \\ \text { CT } & \text { Computed Tomography } \\ \text { EGS } & \text { Engineered Geothermal Systems } \\ \text { ETSD } & \text { Energy and Transportation Science Division } \\ \text { MSTD } & \text { Materials Science and Technology Division } \\ \text { ORNL } & \text { Oak Ridge National Laboratory } \\ \text { RPM } & \text { Revolutions per minute } \\ \text { SNL } & \text { Sandia National Laboratory } \\ \text { TDS } & \text { Total Dissolved Solids }\end{array}$





\section{ACKNOWLEDGMENTS}

This work was performed for the project "Working Fluids and Their Effect on Geothermal Turbines" sponsored by the Geothermal Technologies Program, Office of Energy Efficiency and Renewable Energy, U.S. Department of Energy under contract DE-AC05-00OR22725, Oak Ridge National Laboratory, managed and operated by UT-Battelle, LLC. 



\section{EXECUTIVE SUMMARY}

To address problems such as greenhouse gas emissions and energy security, the US is considering large investments in renewable sources, such as geothermal energy. Hydrothermal systems that have the advantages of plentiful heat, water, and permeable rock already produce about 3000 MWe in the U.S. and more systems are in development. However, the potential for generating electricity from geothermal resources extends well beyond the traditional sources in the Western US. The US Department of Energy is actively supporting research on enhanced and engineered systems that may overcome issues such as low-permeability rock, limited water, and deep well drilling. One issue with engineered geothermal systems is siting. Engineered sites can be located in areas where surface water is limited or water use rights are an issue. One way of minimizing water use is to have a power cycle that can work efficiently with air cooling rather than water cooling. Oak Ridge National Laboratory is developing more efficient power cycles that take advantage of the physical properties of mixtures of refrigerants in Brayton or organic Rankine cycles. Experiments on an air-cooled test loop employing $8 \%$ isobutane in $\mathrm{CO}_{2}$ have given a respectable $13 \%$ cycle efficiency versus a $14.5 \%$ theoretical value for pure super-critical $\mathrm{CO}_{2}$. These experiments are complemented by thermodynamic calculations that have demonstrated the effects of sizing of components in supercritical versus transcritical cycles for mixtures of supercritical $\mathrm{CO}_{2}$ and $\mathrm{SF}_{6}$. In these calculations, air temperatures are varied between 10 and $40^{\circ} \mathrm{C}$ to account for seasonal variability. Extraction of heat from the subsurface represents another aspect of water use in geothermal power. Better understanding of how complex fluid-rock interactions affect heat transport to the surface should facilitate decisions on siting and options to maintain or improve performance during the lifetime of the power plant. These factors contribute to the viability of engineered geothermal technology, especially in arid regions of the country. 



\begin{abstract}
To address problems such as greenhouse gas emissions and energy security, the US is considering renewable resources, such as geothermal energy. Hydrothermal systems produce about $3000 \mathrm{MWe}$ domestically; however, electricity may also come from engineered geothermal systems (EGS) with siting issues such as low-permeability rock, limited water, and deep wells. Water use can be reduced with a power cycle that works efficiently with air cooling, using refrigerant mixtures. Heat extraction from the subsurface represents another aspect of geothermal water use because complex fluid-rock interactions affect heat transport and lifetime performance. These factors all contribute to the viability of EGS.
\end{abstract}

\title{
1. INTRODUCTION
}

Development of alternative sources of energy to fossil fuels are touted as being necessary for energy independence and security, as well as a means to mitigate global climate change through reduced emissions of $\mathrm{CO}_{2}$. In particular, geothermal power, although currently limited to advantageous hydrothermal sites in the Western US with about 3000 MWe capacity, has the potential to provide a tenth of the US electricity requirements (Tester, Anderson et al. 2007). Engineered geothermal systems (EGS) are those that are sited in locations lacking one or more advantageous features: porous rock, high temperature, or an abundant subsurface source of water. Numerous potential sites lack water both within the resource and at the surface for waste heat rejection. The DOE has estimated 100,000 MWe of economically viable energy could be produced from these lower-grade sites with systems designed to overcome the site deficiency (US Department of Energy 2008). For instance, in order to utilize a geothermal resource that lacks sufficient subsurface flow, a working fluid could be injected via wells drilled from the surface. Possible examples are the injection of treated municipal waste water such as done at The Geysers (Majer \& Peterson 2007) or injection of supercritical $\mathrm{CO}_{2}$ (Spycher \& Pruess 2010). Such activities, though, generate additional questions about the uncertainties related to 1 ) how to access these deep formations, 2) how to generate a structure within the formation that allows for fluid to pass through and be heated, and 3) what will happen to the structure over time as this flow occurs.

In addition to engineering of the reservoir, to be economically viable, EGS need to obtain the highest possible power conversion at low cost and to deeply penetrate the market, EGS must be able to operate with lower temperature energy sources and at sites where water availability is limited. Recent work with supercritical mixtures of $\mathrm{CO}_{2}$ and hydrocarbons suggest that power conversion efficiencies approaching $60 \%$ of Carnot efficiency are possible (Lewis, Wright et al. 2011). When coupled to a low temperature geothermal system, efficiencies above $13 \%$ are predicted, which is substantially higher than the conversion efficiency possible with existing organic Rankine power conversion cycles.

Hence, power systems at EGS sites should have the highest possible efficiency to offset the higher cost of site preparation. Many of these sites exist in regions with limited water availability, where the need for water, both for injection into the site and for waste heat rejection, must be controlled. This paper discusses the coupling of a high conversion efficiency supercritical $\mathrm{CO}_{2}$ power conversion cycle to an EGS for sites that could have one or more of the following limitations:

1) Deep resource 
2) Requirement for hydraulic fracturing

3) Lower source rock temperatures

4) Lack of water at the resource temperature

5) Lack of available water at the surface for heat rejection

The amount of water geothermal systems use varies greatly depending upon the definition. One of the difficulties in evaluating use is distinguishing between throughput and consumption. Water use can be defined as the amount of water taken from the environment to be used in an industrial process, and then discharged back into the body of water from which it was drawn. Water consumed by a process, however, is that which is not returned directly to the same aquifer. Losses arise from evaporation, leakage, or contamination such that discharge is not permitted. Geothermal use can range from essentially zero (for binary plants) to values above the average $5400 \mathrm{~L} \cdot \mathrm{MWh}^{-1}$ listed in Table 1 if hydrofracking and power cycle cooling are both taken into account. Understanding how water is used by geothermal is important to improving efficiency and conserving water. Hence, this report focuses on two aspects of water usage in the EGS, underground for mining heat and above ground for cooling in the power cycle.

Table 1. Water Use by Power Sector (Merson 2006)

\begin{tabular}{ll}
\hline \multicolumn{1}{c}{ Utility type } & \multicolumn{1}{c}{ Average water use $\left(\mathbf{L} \cdot(\mathbf{M W h})^{-\mathbf{1}}\right)$} \\
\hline Hydroelectric & 47000 (evaporation from reservoirs) \\
Geothermal (hydrothermal) & 5400 (geyser flash evaporation) \\
Nuclear thermal & 3200 (cooling) \\
Coal (conventional) & 3000 (cooling) \\
Concentrated solar & 2900 (cooling) \\
Gas fired (conventional) & 2300 (cooling) \\
Integrated gas combined cycle (IGCC) & 880 (cooling) \\
Wind & 0 \\
Solar photovoltaics & 0 \\
\hline
\end{tabular}

Specifically, one part of this study was to investigate the structure of geothermal source rock, which will affect the utilization of subsurface water at an EGS site. Such an investigation will ultimately include: 1) characterizing the types of formations at these sites, 2) identifying those most suitable for power production, 3) understanding the processes required and risks associated with preparation of the formation for fluid flow, 4) understanding the potential impact of fluid flow through those formations, and 5) predicting the long-term performance of a geothermal reservoir. In this work we show how we are beginning to measure rock porosity using advanced imaging methods, with the goal of relating the structure of rock to the permeability of fluid downhole.

The second consideration to be discussed here is needed cooling, which alone can use vast amounts of water, depending on if the cooling is open cycle, where water is provided continually by a body of water, or closed cycle, where heat is discharged from cooling water by evaporation in towers. The latter is much more efficient in terms of water usage, by a factor of 30 to 50 , but is also more expensive to design and build. More efficient power generation cycles are being developed that may allow use of lower quality heat resources $\left(90-160^{\circ} \mathrm{C}\right)$. Higher efficiency may come from utilization of unconventional refrigerants in the power generation cycle. Gains in efficiency may also offset the losses from using air cooling rather than water cooling if surface water resources are scarce. Calculations on the theoretical efficiency of systems that use wet or dry cooling show if power generation from arid sites can be made economically viable.

By studying the role of water usage in engineered geothermal, siting should become less uncertain 
with a higher probability of success. Engineered geothermal must be considered if this energy source is to become a significant part of the U.S. energy portfolio, as it expands the range and adaptability of geothermal power many times over while reducing the impact on arid climates. 


\section{COMPUTED TOMOGRAPHIC SCANNING AS A TOOL TO CHARACTERIZE ROCK FORMATIONS}

Research is needed to better understand the microstructure of bedrock in geothermal systems to better site power systems. Finding suitable quantities of thermal energy is relatively easy, but predicting optimal drilling depths and forecasting difficulties arising from heat extraction can be difficult (Jaya, Shapiro et al. 2010). Sampling and knowledge of the aquifer rock porosity should assist in siting and maintenance of an EGS plant. Porosity, $n$, is the volume fraction of voids in the rock. Connected porosity relates the pore velocity, $\mathrm{v}\left(\mathrm{m} \cdot \mathrm{s}^{-1}\right)$, to the flux of fluids through the rock, $q\left(\mathrm{~m} \cdot \mathrm{s}^{-1}\right)$, Equation (1).

$$
v=\frac{q}{n}
$$

If necessary, hydraulic fracturing can be used to increase porosity during drilling. Porosity can also be affected by changes in the subsurface strata occurring during production, such as subsidence or seismic effects from mining the heat (Patel 2009). Accurate measurements of rock porosity could lead to improved success rates for production wells as well as reduced drilling costs by providing data to predict dynamical effects.

The porosity of rock can be determined by numerous methods, such as water impregnation, mercury injection, or gas expansion, which will give an estimate of connected porosity, but all these methods have opportunities for introducing error in the data. Computed tomography (CT) analysis of rocks is a very precise way to detect porosity to the micron scale, but standard analysis only gives total porosity. Neutron imaging gives an overall analysis of rock pore volume and has been used to describe metamorphic rocks down to the nanoscale (Anovitz, Lynn et al. 2009). Permeability, $k$, expressed with units of surface area, often $\mathrm{m}^{2}$, is the characteristic of a site that determines whether wells will be successful, but measurements can be affected by experimental bias. Darcy's law, Equation (2), relates permeability to fluid dynamic viscosity, $\mu(\mathrm{Pa} \cdot \mathrm{s})$, and applied pressure drop per unit length, $\nabla P\left(\mathrm{~Pa} \cdot \mathrm{m}^{-1}\right)$. Units of millidarcies $(\mathrm{mD})$ are the industry standard for measuring permeability in rock strata, corresponding to a $1 \mathrm{~cm}^{3} / \mathrm{s}$ flow of a $1 \mathrm{mPa} \cdot \mathrm{s}$ viscosity fluid achieved over $1 \mathrm{~cm}^{2}$ under a pressure drop of $1 \mathrm{~atm} / \mathrm{cm}$. Although in common use, the expression below is oversimplified for an actual geological formation, as it assumes that the fluid used will encounter pressure gradients that are static, isothermal conditions, and homogeneous source rock composition. Another issue with this expression as applied to in geothermal situations is that Darcy's Law is only applicable to slow moving flow with a viscous fluid, which is not representative of the cyclical high pressure gradients in pulsed geothermal cycles.

$$
q=\frac{-k}{\mu} \nabla P
$$

The thermophysical and thermochemical behavior of the water in the rock is also an important aspect of understanding the effect of drilling and heat production on water resources. Fluid flow will be affected by its chemical composition. The salinity of groundwater at geothermal sites can range from about 6000 ppm chloride ion, such as in the Berlin field, El Salvador (D'Amore \& Mejia 1999), to

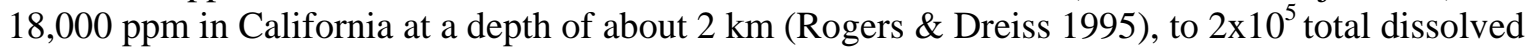
solids (TDS) measured in German samples $\left(4200 \mathrm{~m}, 150^{\circ} \mathrm{C}, 45 \mathrm{MPa}\right)$ (Regenspurg, Wiersberg et al. 2010). The composition of the geothermal water changes over time with production but, except at the highest TDS, can be considered to be primarily $\mathrm{NaCl}_{(\mathrm{aq})}$ (Franke \& Thorade 2010). The viscosity does not change much with subsurface pressure, but models show an exponential drop in viscosity with 
temperature. For instance a $2.25 \times 10^{5}$ TDS brine has a viscosity of $0.0018 \mathrm{~Pa} \cdot \mathrm{s}$ at $25^{\circ} \mathrm{C}$ that drops to $0.0003 \mathrm{~Pa} \cdot \mathrm{s}$ at $190^{\circ} \mathrm{C}$ (Franke \& Thorade 2010). Calculation of flow rate versus permeability shows that the hydraulic head has the greatest effect on the flow rate through the rock.

Factors that affect flow calculations include the fact that the geothermal fluid has many inorganic components as well as dissolved gases, which lead to variations in density particularly during pumping. Fluid dynamics effects and differences between start-up and production periods are also not brought into the Darcy model. The highly mineralized water will undergo changes in state as it is brought to the surface. It can be flashed to steam to directly turn a turbine, or can be used to deliver energy to a heat exchanger. As the water cools, minerals will precipitate and must be removed from a closed cycle system. Mineral formation can also occur underground, changing the characteristics of the reservoir (Kralj \& Rychagov 2010). If hydraulic fracturing is used to increase porosity, the water returning to the surface will have different flow characteristics and chemical composition than native subsurface water. 


\section{POROSITY MEASUREMENTS USING SCANNING TOMOGRAPHY}

An x-ray microtomography instrument was used to analyze rock samples from various origins, including samples from the Geysers in California, several different grades of coal, and various sedimentary rock types. The samples were chosen to compare the porosity of rock that is typically used for hydrothermal purposes (such as geyser rock) and with the porosity of other rocks of importance in energy generation (including shale rock and coal). Examples of pore volumes reported in the literature are given in Table 2.

Table 2. Examples of pore volumes of rock samples

\begin{tabular}{|c|c|c|c|}
\hline Type of rock & Pore volume fraction & Method of measurement & $\begin{array}{c}\text { Use in energy } \\
\text { generation }\end{array}$ \\
\hline Metamorphic & $0.01-0.10$ & $\begin{array}{l}\text { Neutron scattering } \\
\text { (Anovitz, Lynn et al. } \\
\text { 2009) }\end{array}$ & Surface material - mining \\
\hline Shales - mudrock & $0.1-0.5$ & $\begin{array}{l}\text { Helium, mercury } \\
\text { (Dorsch \& Katsube 1996) }\end{array}$ & Unconventional gas \\
\hline Sandstone & $0.3-0.6$ & $\begin{array}{l}\text { Nuclear magnetic } \\
\text { resonance } \\
\text { (Daigle \& Dugan 2011) }\end{array}$ & Subsurface aquifer \\
\hline Igneous - volcanic & $<0.15$ & $\begin{array}{l}\text { Isopiestic measurements } \\
\text { (Gruszkiewicz, Horita et } \\
\text { al. 2001) }\end{array}$ & Geothermal \\
\hline
\end{tabular}

Although the data in Table 2 are non-representative examples of the rock microstructure, they illustrate that igneous rocks that are often the source of geothermal power have lower porosity than shales or sandstones. The flow of fluid through the geothermal bed can be affected by microfractures and channels as well as pore volume. Water to replenish the geothermal bed can come from more porous strata that are nearby, or from engineered injection sites. An issue with many of the methods used to characterize these geological samples is that the results from bulk measurements can be skewed to preferentially sample larger pores. The work described here explains how multi-scale microscopic measurements can be used to build up a larger picture of the pore structure using statistical analyses of rock images.
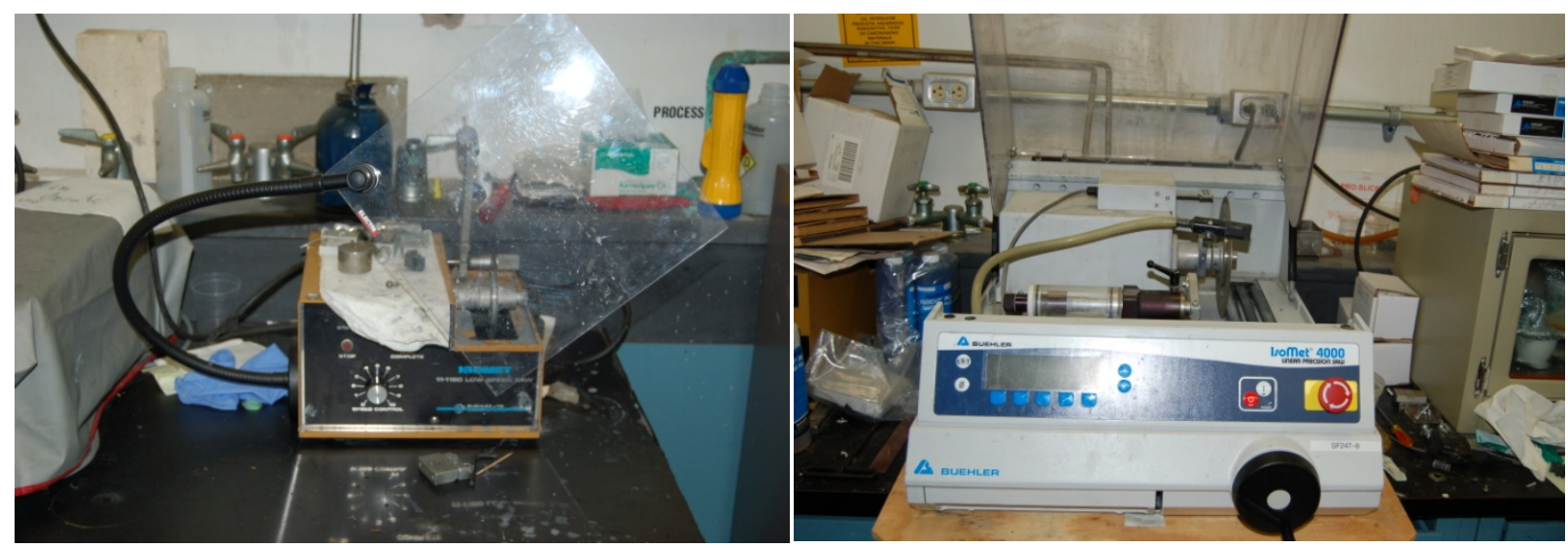

Fig. 1. Diamond saws used for cutting rock samples

Sample preparation began with cutting intact rock samples into $\sim 5 \times 5 \times 5 \mathrm{~mm}^{3}$ cubes by use of two 
diamond saws, Fig. 1, the larger one running up to 4000 RPM. These cubes were then mounted onto thin shafts using Duco Cement for scanning tomography for characterization and porosity measurements.
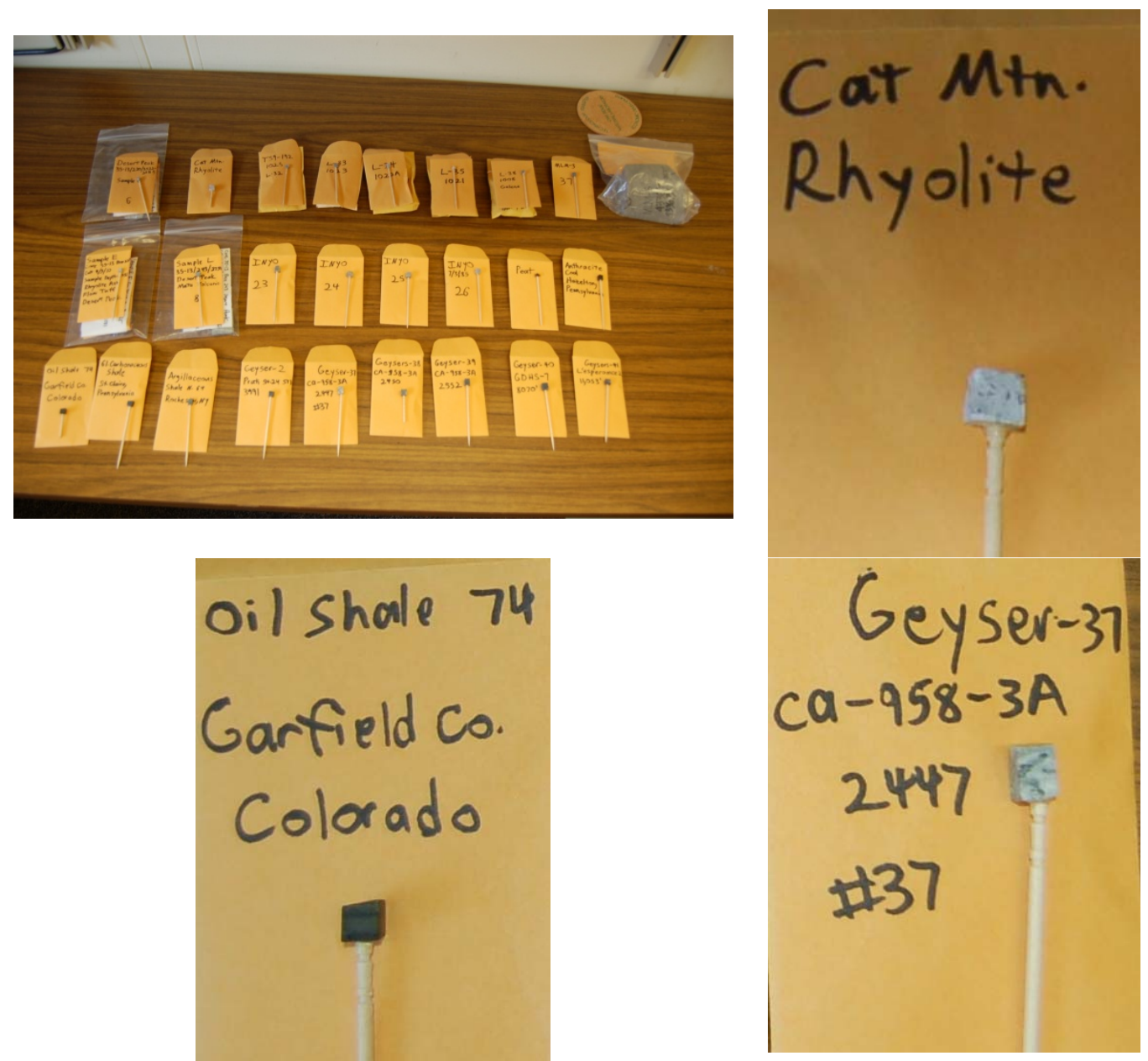

Fig. 2. Rock samples prepared for CT analysis

The scanner, an X-Radia microXCT instrument custom built for ORNL, contains a tungsten microfocus $\mathrm{x}$-ray source, a thin single crystal scintillator of thallium-doped cesium iodide, and a 2048x2048 pixel Peltier-cooled charge-coupled detector (CCD), Fig. 3. The components were aligned with an $\mathrm{X}$-Radia alumina alignment sphere. The $\mathrm{x}$-ray source was operated at $100 \mathrm{kV}$ and 8 watts. Scans were run from $-90^{\circ}$ to $+90^{\circ}$ at both small angle and large angle resolutions: low penetration (181 angles, 30 second exposure) or overnight at very high penetration (451 angles, 60 second exposure). Kitware VolView 2.0 software was used to create three dimensional visualizations from reconstructed tomographic data. The software can be used to create "videos" focusing on the aspect of the specimen of interest. In the images below, the pores show up as dark areas, whereas highly dense material is indicated as a bright spot. 


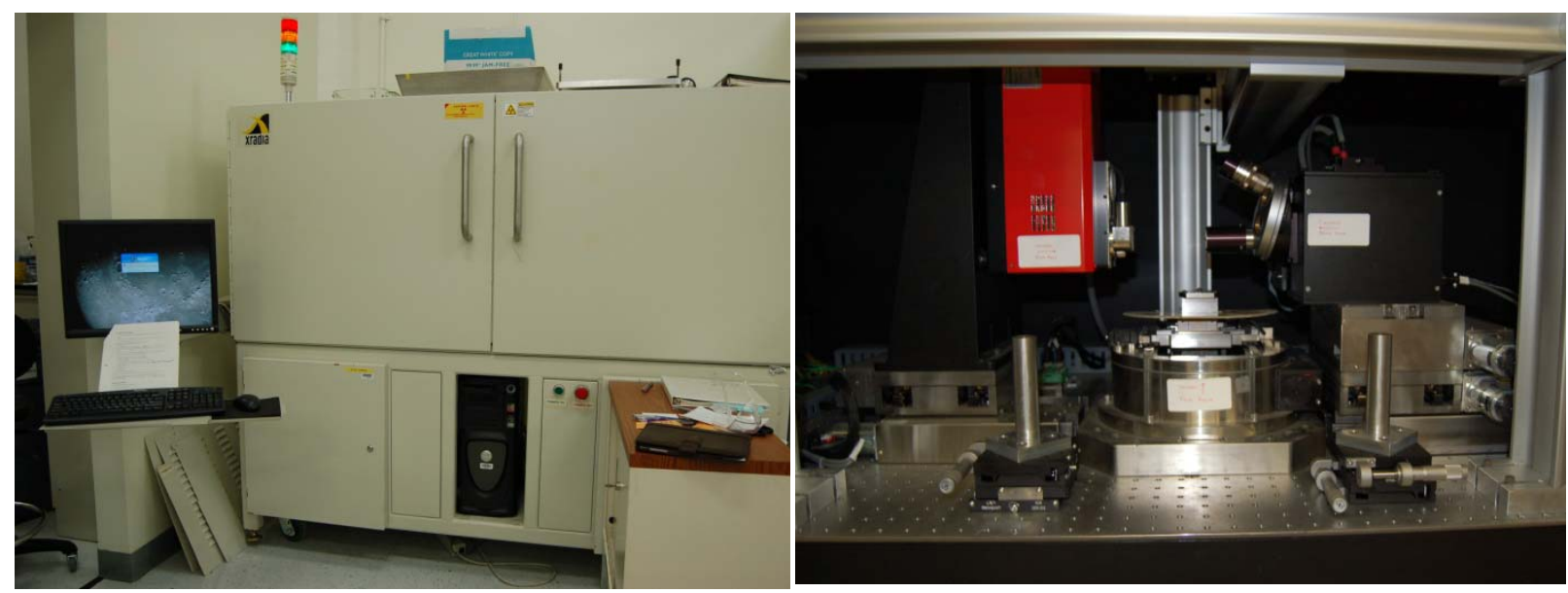

Fig. 3. X-Radia CT scanner

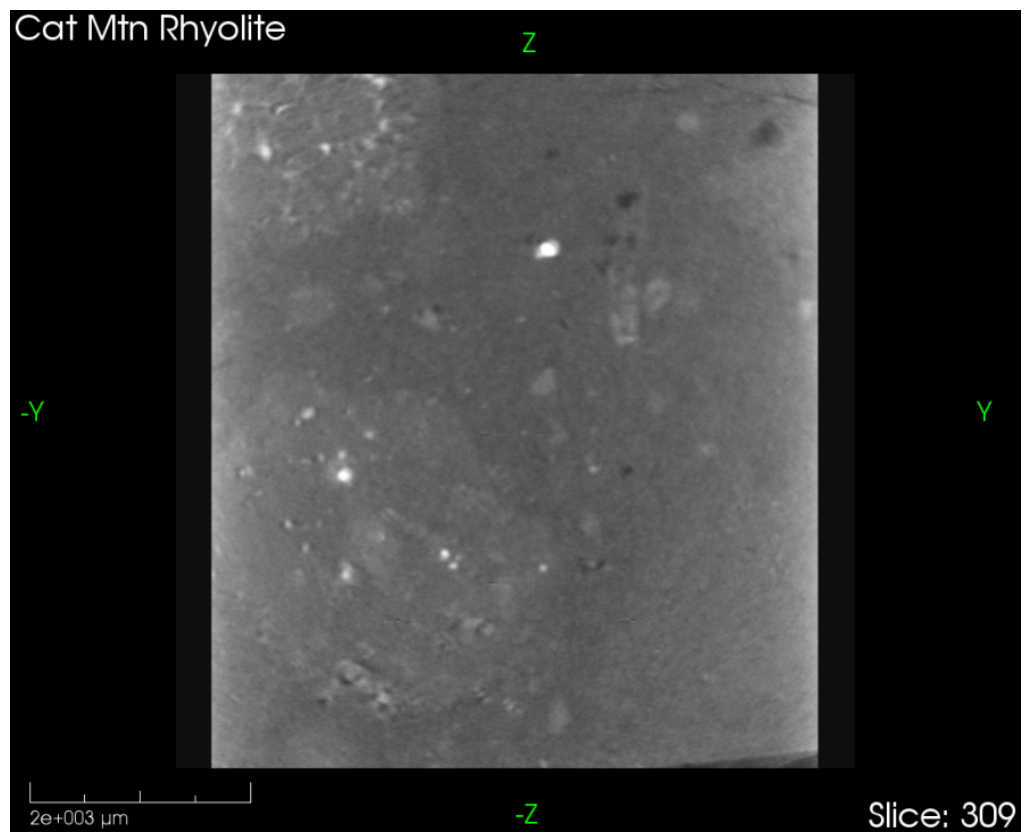

Fig. 4. CT image of a Cat Mountain Rhyolite 

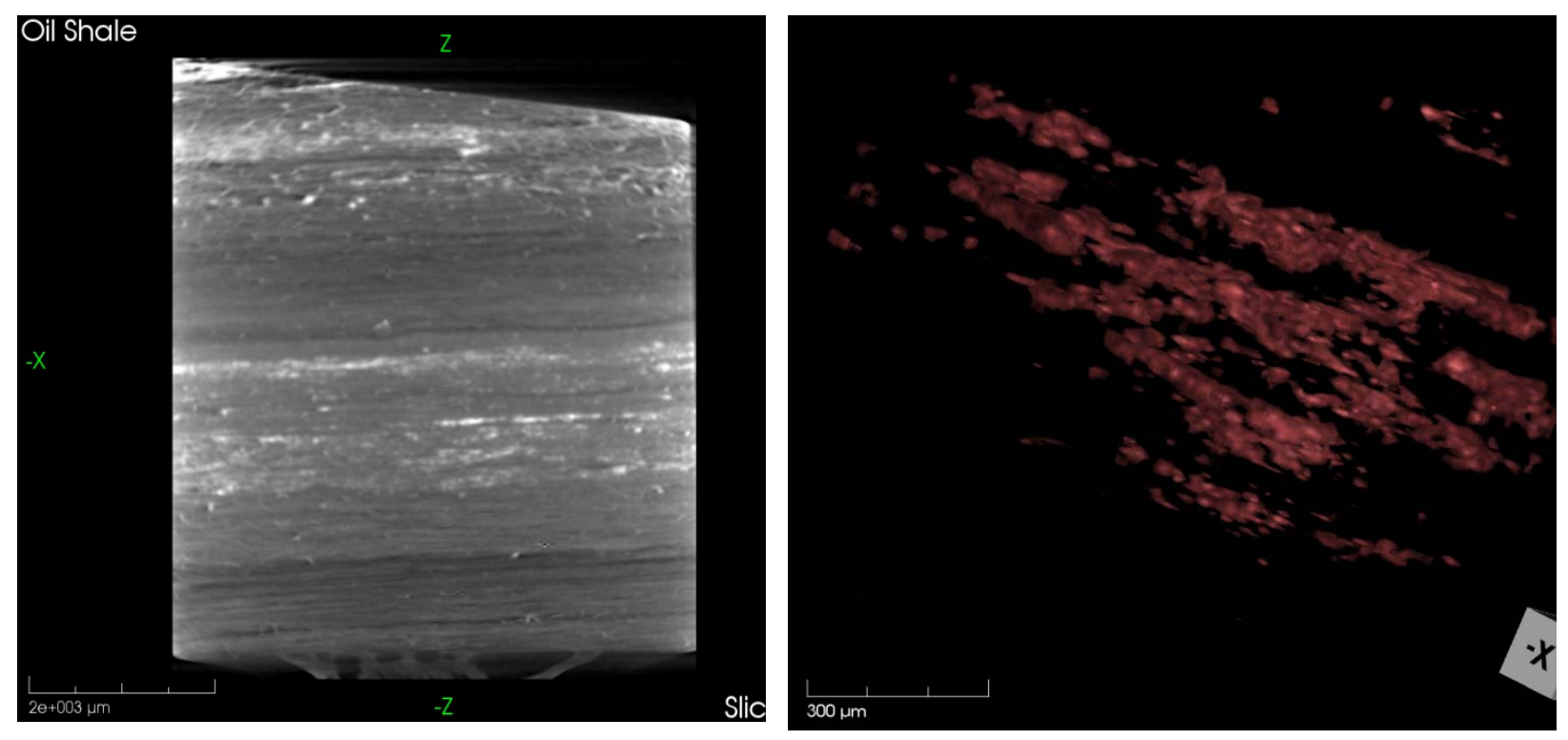

Fig. 5. Oil shale (standard scan on left) and enhanced pore image (false color and tilted on right).

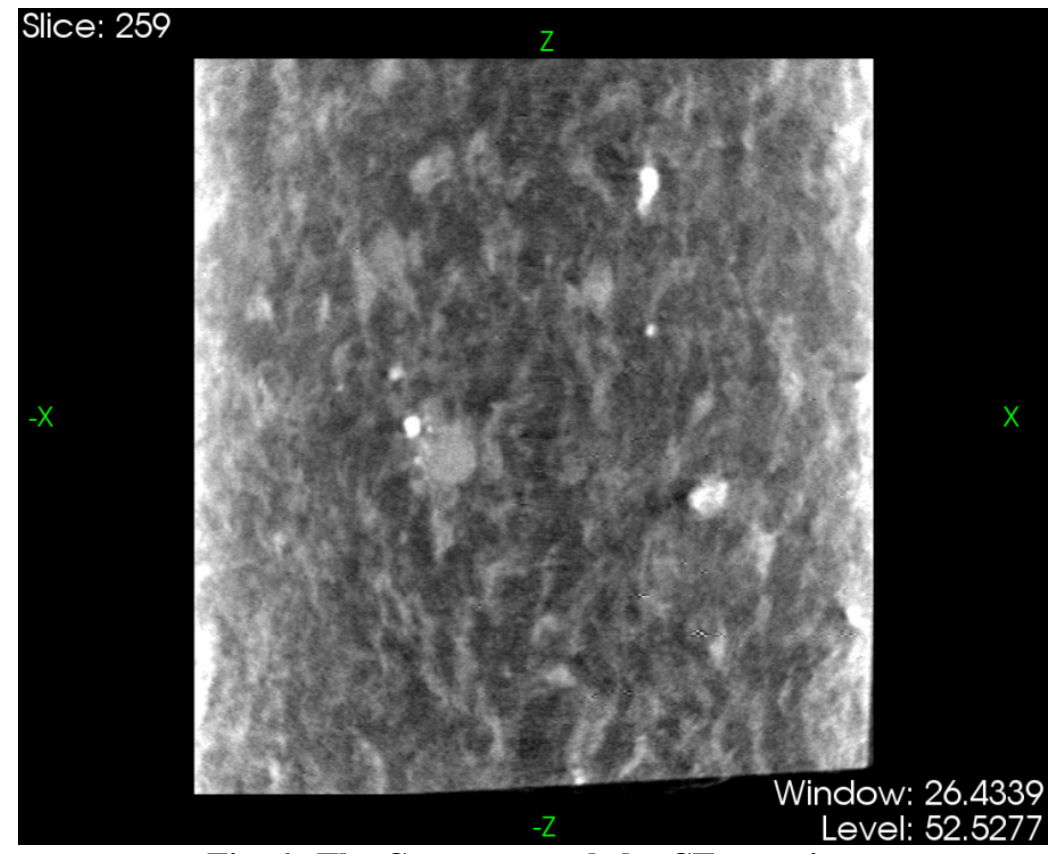

Fig. 6. The Geysers sample by CT scanning

Not all the samples prepared and shown in Fig. 2 have been analyzed. At the time of writing this paper, the samples that have been imaged included a quartz rhyolite from Cat Mountain in Arizona, Fig. 4, an oil shale from Colorado, Fig. 5, and rock from The Geysers in California, Fig. 6. The Geysers is one of the largest geothermal plants at a capacity of 725 MWe. As expected, the rhyolite from Cat Mountain showed little porosity and bedding, but more inclusions than either the Geysers' rock or the oil shale from Colorado. The oil shale shows bedding typical of sedimentary rock, with strata of pores (the dark areas) and dense material (the lighter areas). The slices have been merged into a 3-D image of the pores in the rock, falsely colored and tilted to better display the bedding, Fig. 5. Although not seen in these samples, scanning can show microfractures quite well, and along with pore distributions, and gives a clearer understanding of the inhomogeneous density profiles in 
rock strata. Fracturing through bedding, co-location of pores along grain boundaries, as well as overall pore volume will affect permeability in the rock. Image analysis software can give a statistical estimate of the overall porosity in the rock, the pore size distribution as well as the interconnectedness of the pores through correlation analysis (Anovitz, Lynn et al. 2009).

This work has just begun to apply 3-D imaging and high power computing resources to understand the rock morphology. This study will relate to geothermal water usage and system efficiency by allowing the prediction of pumping power required to move fluid through the rock formation and return it to the surface, sometimes from as deep as $10 \mathrm{~km}$. The hydraulic pressure in these systems will depend on the pumping fluid composition and density, which are related to fluid selection, minor constituents, rock formation, and depth. The fluid injected into the ground will change composition because of fluid and rock interactions (Giorgetti, Mata et al. 2000). In addition, the heating of the fluid will change over time, because of thermal gradients in the geothermal field. Changes in the rock structure from fluid injection, as well as changes in the chemistry of the downhole fluid will directly affect flow to the surface and required pumping power. Because of the complexity of the physical processes, these phenomena have not been studied quantitatively, although detailed descriptions of geothermal formations have been published, for example (Moore, Hickman et al. 2001). However, computational tools now being developed to explore and analyze data from the nano to macroscale (Li \& Horne 2009), and to predict changes in structure over time. 


\section{AIR COOLING VERSUS WATER COOLING IN BINARY POWER CYCLES}

\subsection{CONCEPTUAL DESIGN OF SUPERCRITICAL $\mathrm{CO}_{2}$ SYSTEM COUPLED WITH EGS}

Traditional geothermal has an approximate thermal efficiency approaching $12 \%$, depending on heat source and sink temperatures. Most production sites are not ideal in that they either have a lower than desired source temperature or inadequate means of heat rejection. Advanced power conversion cycles are being considered to generate electricity from lower-temperature heat sources. Although temperatures of greater than $300^{\circ} \mathrm{C}$ can be expected for the deepest geothermal wells, the range of temperatures for the majority of EGS sites goes from $100-220^{\circ} \mathrm{C}$. In this range, the cycles that can be used include advanced Rankine and supercritical $\mathrm{CO}_{2}$ cycles for binary power generation. The work has been extended further to include mixtures of $\mathrm{CO}_{2}$ with other inert gases to investigate if enhancement in efficiency can be gained from the use of non-traditional fluids that will compensate for either a lower quality heat source, or warmer heat sink.

Investigations of binary power production, described in detail elsewhere (Sabau, Yin et al. 2011), has included both modeling and experimental components looking at mixtures of $\mathrm{CO}_{2}-\mathrm{SF}_{6}$ and $\mathrm{CO}_{2}-$ isobutane in subcritical Rankine and supercritical Brayton cycles. Mixtures of refrigerants were tested by simulation to optimize the coupling of the geothermal heat source to power generation. Thermodynamic properties were generated using the National Institute of Standards Technology (NIST) REFPROP database (Lemmon \& Jacobsen 2004), but discrepancies were observed in the prediction of the saturation line and critical behavior of the mixtures. Hence, measurement and derivation of thermophysical properties had to be carried out. For instance, the mixture of $\mathrm{SF}_{6}$ and $\mathrm{CO}_{2}$ is highly non-ideal, showing positive excess molar volumes under some conditions, and negative under others. Hence, the critical point for the mixture can be much reduced from that of either fluid on its own, allowing the system to stay supercritical over a wider range of temperatures, Fig. 7.

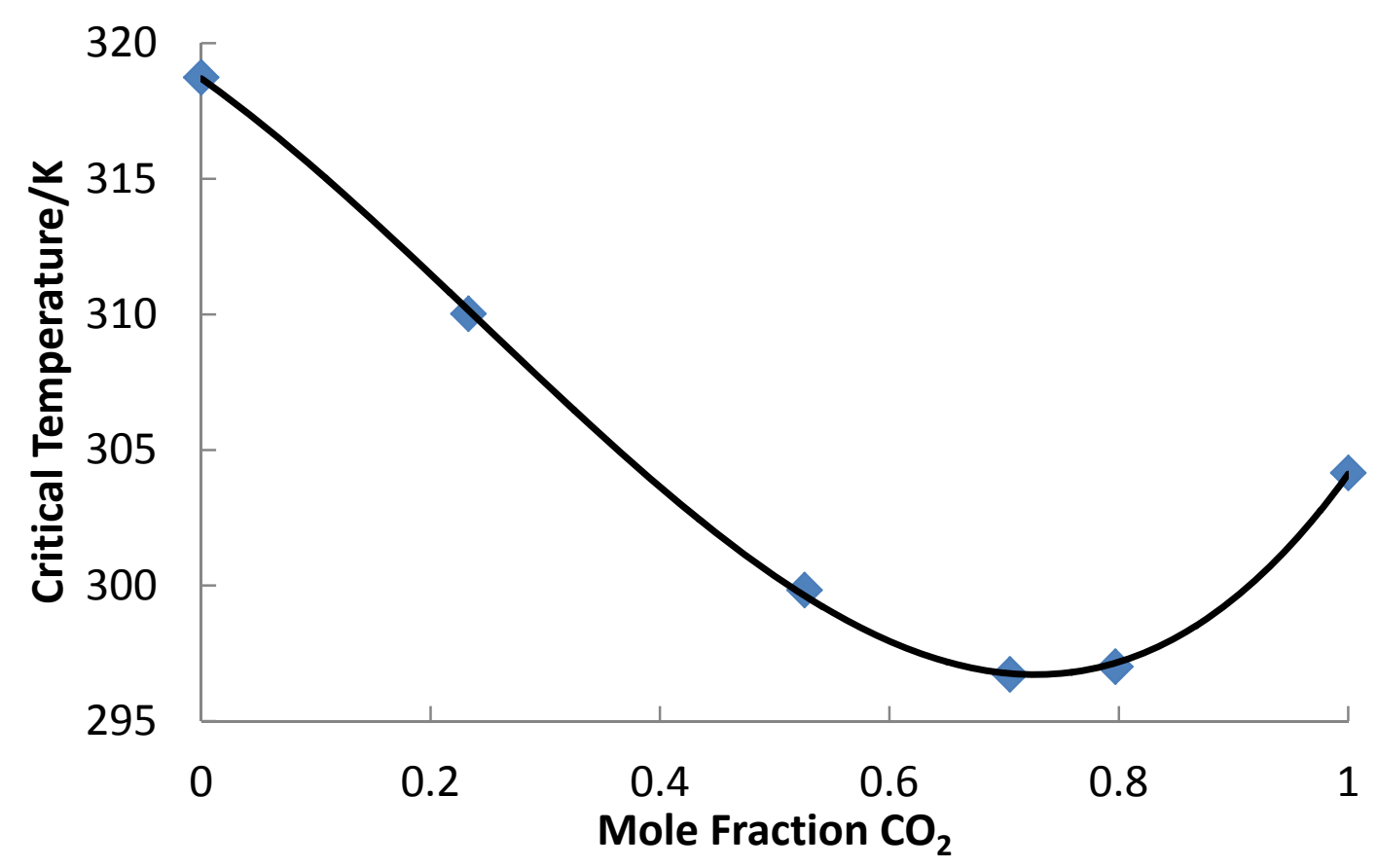

Fig. 7 Critical Point of $\mathbf{C O}_{2} / \mathbf{S F}_{\mathbf{6}}$ mixtures. Data were taken from Diefenbacher \& Turk (2001). 


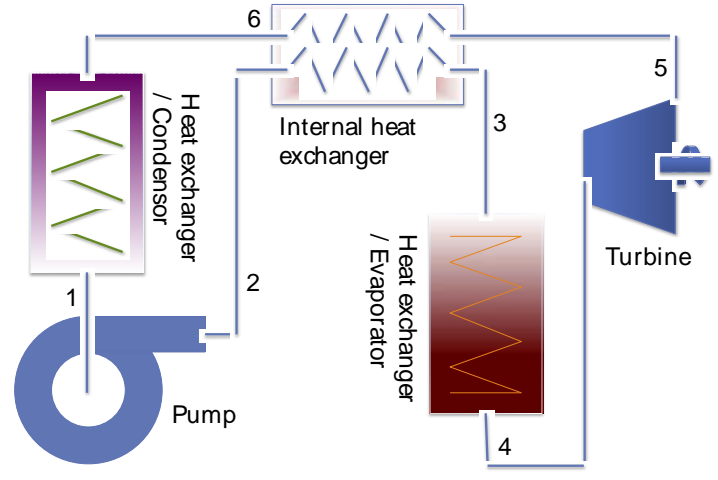

Fig. 8. Rankine cycle showing the changes in the working fluid as it passes through the cycle: (1) exiting the condenser; (2) pumped to the preheater; (3) heated by the external source i.e., groundwater; (4) heated, it passes through the turbine; (5) excess heat is captured in the heat exchanger, and (6) cooled with an external fluid.
In the thermodynamic calculations carried out for a Rankine power cycle, Figure 8, (Sabau, Yin et al. 2011) parameters that were preset included: the geothermal source water temperature and flow rate, the composition of the working fluid, from 0 to $45 \mathrm{~mol} \% \mathrm{SF}_{6}$ in $\mathrm{CO}_{2}$, working fluid flow rate, coolant inlet temperature and pumping speed, pump inlet temperature and pressure, cycle pressure ratio and pressure drop over the heat exchanger. The areas of the condenser and evaporator heat exchangers were varied to close the cycle and the efficiency was calculated. The results of the simulations showed that the efficiency of the cycle could be enhanced from $6 \%$ (pure $\mathrm{CO}_{2}$ at $5 \mathrm{MPa}$ ) to $\sim 13 \%\left(>30 \% \mathrm{SF}_{6}\right.$ in $\mathrm{CO}_{2}$ at $5 \mathrm{MPa}$ ). Lower concentrations of $\mathrm{SF}_{6}$ involved a purely supercritical or Brayton cycle, and the higher concentrations of $\mathrm{SF}_{6}$ in $\mathrm{CO}_{2}$ followed a Rankine cycle with condensation. If condensation of the mixture was avoided and the pump inlet pressure

boosted to $8 \mathrm{MPa}$, cycle efficiencies of $9-11 \%$ were achieved for a wide range of $\mathrm{CO}_{2}-\mathrm{SF}_{6}$ mixtures, values almost double that calculated for the baseline case of pure $\mathrm{CO}_{2}$. For air cooling in hot dry locations, supercritical operation without condensation would be the best choice for binary geothermal power production. There would be some loss in efficiency relative to water-cooled systems (Sandler 1999), but with a judicious choice of working fluid, the cycle should have the same performance as standard EGS platforms.

\subsection{EXPERIMENTAL VALIDATION OF GEOTHERMAL LOOP PERFORMANCE}

Pilot-scale development and demonstration testing is currently underway at Sandia National Laboratories (SNL) for supercritical $\mathrm{CO}_{2}$ Brayton power conversion systems. In addition to pure $\mathrm{CO}_{2}$, mixtures of $\mathrm{CO}_{2}$ with $\mathrm{SF}_{6}, \mathrm{CO}_{2}$ with butane, and $\mathrm{CO}_{2}$ with noble gases have been studied to evaluate how the change in physical properties affects the performance of the compressor in the cycle at different fluid densities. Specifically, the experiments were designed to test the mixture equation of state through pressure and temperature measurements and to compare the data to REFPROP calculations. In addition, the critical point of the mixture could be estimated by the onset of mass flow oscillations as the system was cooled through the saturation curve.

These laboratory experiments have demonstrated all required technology at power levels approaching $250 \mathrm{~kW}(\mathrm{e})$ and indicate that power levels beyond $1 \mathrm{MW}(\mathrm{e})$ are well suited to the Brayton cycle technology. Experimental data for the saturation curve for $\mathrm{CO}_{2}$ and butane appeared to be similar in shape, but a few degrees lower than that predicted by REFPROP. Because of numerous data on the $\mathrm{CO}_{2}$ /butane mixture that have been incorporated into parameters used to calculate thermophysical properties, the REFPROP simulation appears to be reliable, Figure 9. The mixture of $\mathrm{CO}_{2}$ and $\mathrm{SF}_{6}$ had a dramatically lower critical temperature than expected because of non-ideal behavior, Figure 7. This behavior was not predicted by REFPROP calculations, which did reproduce $\mathrm{T}, \mathrm{P}$, and density diagrams quite well. In the case of $\mathrm{CO}_{2}$ /neon, a greater difference was observed in the critical pressure upon mixing than the critical temperature. 


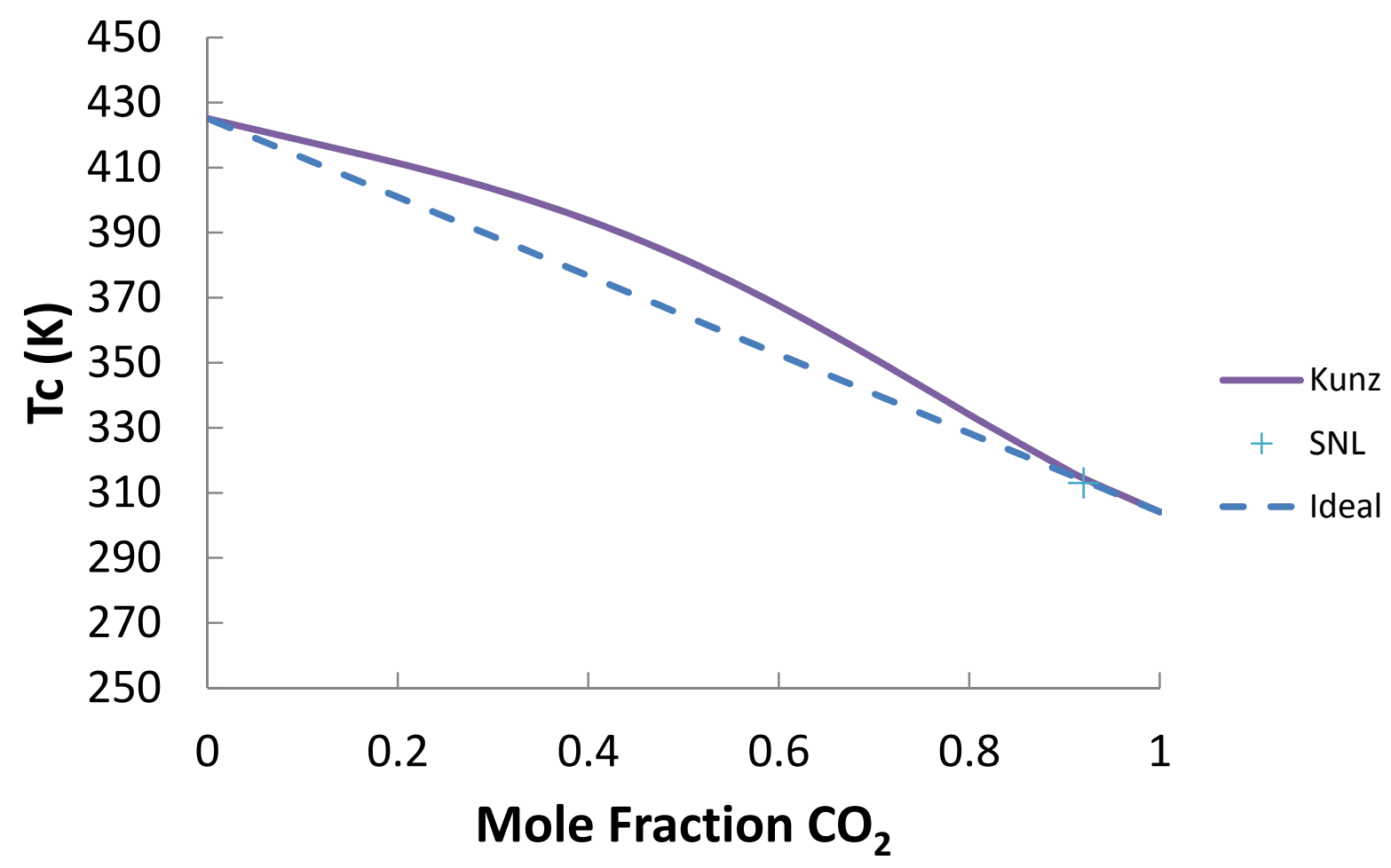

Fig. 9. Critical temperature as a function of $\mathrm{CO}_{2}$ mole fraction for $\mathrm{CO}_{2} /$ nbutane mixtures. The REFPROP simulation (purple) was based on data from (Kunz, Klimeck et al. 2006).

Experimental efforts at SNL suggest that the efficiency of geothermal power systems can be higher than that of organic Rankine systems using mixtures of supercritical $\mathrm{CO}_{2}$ and organics or noble gases, especially where a power cycle enhancement is included such as split flow recuperators to enhance heat recovery (Kuppan 2000). Although there are remaining development issues, the technology could readily be adapted for use with EGS systems. The experiments and calculations were performed for dry cooling, with the coolant input temperature was set at a relatively high $40^{\circ} \mathrm{C}$. In agreement with the thermodynamic system calculations discussed earlier, if a mixture is chosen with a critical point several degrees above the coolant temperature, then dry cooling becomes feasible. For operation with air cooling, mixtures of $\mathrm{CO}_{2}$ and a hydrocarbon such as butane or hexane that show increased critical temperatures because of non-ideal behavior would be preferable over pure $\mathrm{CO}_{2}$, or mixtures that exhibit lower critical temperatures than an ideal mixture of pure fluids.

Although preliminary testing has been done, further investigation is needed to identify the heat source and sink temperature combinations that would be favorable for EGS supercritical $\mathrm{CO}_{2}$ power systems. A conceptual design effort would focus on the equipment required to couple the heat from the source into the supercritical working fluid and the equipment required to reject waste heat to the environment. Key issues include 1) the requirements on fluids required to extract the heat from the rock formations, 2) pumping power requirements and anticipated heat losses on the hot side of the cycle, and 3) the extent to which the availability of water plays a role in the performance of these systems, especially in regards to heat rejection capacity and minimum low end temperature. The existing generic model would be updated to include representations of EGS components and to estimate their impact on overall system performance by addressing issues of piping requirements, heat exchanger sizing and pressure drop through rock formations. 


\section{DISCUSSION AND CONCLUSIONS}

Geothermal systems are complex, particularly when the goal is to boost the efficiency of otherwise marginal sites through engineering. In siting, both the structure of the geosphere and available water resources for drilling as well as for cooling during operation are important. Long term effects on the geology and hydrology also must be considered.

Understanding the porosity of a variety of geologic formations will provide a template for better predicting suitable sites, while producing the beginnings of a database for geologic formation characterization across the country, allowing information about drilling sites and heat sources to be more accessible. This study of rock microstructure will be invaluable to predicting permeability of source fluid and heat transfer through a formation and how the well may perform as a heat source over time. A variety of samples should be collected from a site of interest at different depths to better understand the geology and transport of heat and water throughout the geosphere. A statistical analysis of overall porosity can be done comparing rock structures of hydrothermal systems, such as The Geysers, with EGS sites from which it is more difficult to extract heat. Competing factors may affect decisions about siting, such as depth versus porosity, drilling through hard cap to reach permeable rock, or decisions about the optimal number of wells in a particular resource. However, these criteria will be more easily prioritized with detailed information about the geological formation.

Power cycle and surface water resources also affect siting decisions. Source temperature, sink temperature, and fluid properties all have influence on power cycle efficiency, and must be taken into account when designing an EGS power system. Sink temperatures have a stronger effect on cycle efficiency than do source temperatures, so it is important to keep heat rejection temperatures as low as possible. Fluid mixture property experimentation is still very new, but it has the potential to become the most important factor in EGS performance. This modeling effort will investigate how altering and maintaining fluid properties can help overcome site deficiencies to potentially expand the use of geothermal power.

The purity requirements of downhole fluids require additional investigation as well. The Geysers' geothermal power plants have demonstrated that lightly purified water will perform as needed, while having minimal effects on equipment life and maintenance costs. The ability to maintain an acceptable level of purity of the working fluid and the heating fluid needs to be understood, giving engineers the tools to place limits on contaminant level based on performance parameters and risk assessment (Bruel 2002). Robust systems that have flexibility in fluid purity combined with materials developed to handle high salinity flows may allow non-potable or brackish water to be used for heat extraction, as has been done for shale gas recovery and hydraulic fracturing (Ji, Settari et al. 2009), reducing the stress on potable and fresh water resources.

The increase in success and/or efficiency in geothermal siting and operation could greatly alleviate the stress water use for power generation puts on the surrounding environment. The use of water is coupled to lifestyle and the status of the U.S. as a developed nation. Water resources are becoming increasingly monitored and controlled, particularly in arid climates. As demand for alternative power increases so will the demand for water, further raising the importance of efficient use of this resource. This effort will continue with the study of rock permeability, rock-fluid interactions, working fluid enhancements, and cost effective - yet efficient power cycles to improve our understanding of engineered geothermal power production and could expand the available geothermal resource while minimizing water usage in drier locations. 


\section{REFERNCES}

Anovitz, L. M., Lynn, G. W., Cole, D. R., Rother, G., Allard, L. F., Hamilton, W. A., Porcar, L. \& Kim, M.-H. (2009). A new approach to quanitification of metamorphism using ultra-small and small angle neutron scattering. Geochimica et Cosmochimica Acta, Vol. 73, pp. (7303-7324), 00167037.

Bruel, D. (2002). Impact of induced thermal stresses during circulation tests in an engineered fractured geothermal reservoir - Example of the Soultz-sous-Forets European Hot Fractured Rock Geothermal Project, Rhine Graben, France. Oil \& Gas Science and Technology-Revue De L Institut Francais Du Petrole, Vol. 57, No. 5, pp. (459-470), 1294-4475.

D'Amore, F. \& Mejia, J. T. (1999). Chemical and physical reservoir parameters at initial conditions in Berlin geothermal field, El Salvador: A first assessment. Geothermics, Vol. 28, No. 1, pp. (45-73), 0375-6505.

Daigle, H. \& Dugan, B. (2011). An improved technique for computing permeability from NMR measurements in mudstones. Journal of Geophysical Research-Solid Earth, Vol. 116, No. B08101, 0148-0227.

Diefenbacher, A. \& Turk, M. (2001). Critical properties $\left(\mathrm{P}_{c}, \mathrm{~T}_{\mathrm{c}}\right.$, and $\left.\rho_{c}\right)$ and phase equilibria of binary mixtures of $\mathrm{CO}_{2}, \mathrm{CHF}_{3}, \mathrm{CH}_{2} \mathrm{~F}_{2}$, and $\mathrm{SF}_{6}$. Fluid Phase Equilibria, Vol. 182, No. pp. (121-131), 0378-3812.

Dorsch, J. \& Katsube, T. J. (1996). Effective porosity and pore-throat sizes of mudrock saprolite from the nolichucky shale within Bear Creek Valley on the Oak Ridge Reservation: Implications for contaminant transport and retardation through matrix diffusion, Oak Ridge National Laboratory, Oak Ridge, TN, ORNL/GWPO-025.

Franke, H. \& Thorade, M. (2010). Density and viscosity of brine: An overview from a process engineers perspective Chemie der Erde - Geochemistry, Vol. 70, No. 3, pp. (23-32), 0009-2819.

Giorgetti, G., Mata, M. P. \& Peacor, D. R. (2000). TEM study of the mechanism of transformation of detrital kaolinite and muscovite to illite/smectite in sediments of the Salton Sea Geothermal Field. European Journal of Mineralogy, Vol. 12, No. 5, pp. (923-934), 0935-1221.

Gruszkiewicz, M. S., Horita, J., Simonson, J. M., Mesmer, R. E. \& Hulen, J. B. (2001). Water adsorption at high temperature on core samples from The Geysers geothermal field, California, USA. Geothermics, Vol. 30, No. 2-3, pp. (269-302), 0375-6505.

Jaya, M. S., Shapiro, S. A., Kristinsdottir, L. H., Bruhn, D., Milsch, H. \& Spangenberg, E. (2010). Temperature dependence of seismic properties in geothermal rocks at reservoir conditions. Geothermics, Vol. 39, No. 1, pp. (115-123), 0375-6505.

Ji, L. J., Settari, A. \& Sullivan, R. B. (2009). A Novel Hydraulic Fracturing Model Fully Coupled With Geomechanics and Reservoir Simulation. SPE Journal, Vol. 14, No. 3, pp. (423-430), 1086055X.

Kralj, P. \& Rychagov, S. (2010). Zeolites in volcanic-igneous hydrothermal systems: a case study of Pauzhetka geothermal field (Kamchatka) and Oligocene Smrekovec volcanic complex (Slovenia). Environmental Earth Sciences, Vol. 59, No. 5, pp. (951-956), 1866-6280.

Kunz, O., Klimeck, R., Wagner, W. \& Jaeschke, M. (2006). The GERG-2004 Wide-Range Reference Equation of State for Natural Gases and Other Mixtures, VDI-Verlag, Düsseldorf, Germany.

Kuppan, T. (2000). Heat Exchanger Design Handbook, Marcel Dekker, Inc, ISBN 0-8247-97876, New York, NY. 
Lemmon, E. W. \& Jacobsen, R. T. (2004). Equations of state for mixtures of R-32, R-125, R134a, R-143a, and R-152a. Journal of Physical Chemistry Reference Data, Vol. 33, No. 2, pp. (593620 ),

Lewis, T., Wright, S. \& Conboy, T. (2011). Supercritical $\mathrm{CO}_{2}$ mixture behavior for advanced power cycles and applications, Supercritical $\mathrm{CO}_{2}$ Power Cycle Symposium, May 24-25, 2011, Boulder CO, USA.

Li, K. W. \& Horne, R. N. (2009). Experimental Study and Fractal Analysis of Heterogeneity in Naturally Fractured Rocks. Transport in Porous Media, Vol. 78, No. 2, pp. (217-231), 0169-3913.

Majer, E. L. \& Peterson, J. E. (2007). The impact of injection on seismicity at The Geysers, California Geothermal Field. International Journal of Rock Mechanics and Mining Sciences, Vol. 44, No. 8, pp. (1079-1090), 1365-1609.

Merson, J. (2006). Energy Demands on Water Resources: Report to Congress on the Interdependency of Energy and Water, Washington, DC.

Moore, D. E., Hickman, S., Lockner, D. A. \& Dobson, P. F. (2001). Hydrothermal minerals and microstructures in the Silangkitang geothermal field along the Great Sumatran fault zone, Sumatra, Indonesia. Geological Society of America Bulletin, Vol. 113, pp. (1179-1192), 1050-9747.

Patel, S. (2009). Assessing the Earthquake Risk of Enhanced Geothermal Systems. Power, Vol. 153, No. 12, pp. (62-69), 0032-5929.

Regenspurg, S., Wiersberg, T., Brandt, W., E., H., Saadata, A., Schmidt, K. \& Zimmermann, G. (2010). Geochemical properties of saline geothermal fluids from the in-situ geothermal laboratory Groß Schönebeck (Germany) Chemie der Erde - Geochemistry, Vol. 70, No. 3, pp. (3-12), 00092819.

Rogers, D. B. \& Dreiss, S. J. (1995). Saline groundwater in Mono basin, California .1. Distribution. Water Resources Research, Vol. 31, No. 12, pp. (3131-3150), 0043-1397.

Sabau, A. S., Yin, H., Pawel, S. J., Gruszkiewicz, M., McFarlane, J., Conklin, J. C. \& Qualls, L. A. (2011). Mixtures of $\mathrm{CO}_{2}-\mathrm{SF}_{6}$ as working fluids for geothermal plants. Proceedings of ASME 2011 International Mechanical Engineering Conference and Exposition, Denver, CO, USA.

Sandler, S. I. (1999). Chemical and Engineering Thermodynamics, ( $3^{\text {rd }}$ Ed.), John Wiley \& Sons, ISBN 0-471-18210-9, New York, NY.

Spycher, N. \& Pruess, K. (2010). A Phase-Partitioning Model for $\mathrm{CO}_{2}$-Brine Mixtures at Elevated Temperatures and Pressures: Application to $\mathrm{CO}_{2}$-Enhanced Geothermal Systems. Transport in Porous Media, Vol. 82, No. 1, pp. (173-196), 0169-3913.

Tester, J. W., Anderson, B. J., Batchelor, A. S., Blackwell, D. D., DiPippo, R., Drake, E. M., Garnish, J., Livesay, B., Moore, M. C., Nichols, K., Petty, S., Toksoz, M. N., Veatch, R. W., Baria, R., Augustine, C., Murphy, E., Negraru, P. \& Richards, M. (2007). Impact of enhanced geothermal systems on US energy supply in the twenty-first century. Philosophical Transactions of the Royal Society a-Mathematical Physical and Engineering Sciences, Vol. 365, No. 1853, pp. (1057-1094), 1364-503X.

US Department of Energy, E. E. R. E. (2008). Geothermal Tomorrow, Geothermal Technologies Program. 


\section{INTERNAL DISTRIBUTION}
1. L.M. Anovitz
2. A.K. Kercher
3. T.J. King, Jr.
4. J. McFarlane
5. A.L. Qualls

6. K.J. Qualls

7. A.S. Sabau

8. R.L. Snead

9. H. Yin
10. ORNL Office of Technical Information and Classification

\section{EXTERNAL DISTRIBUTION}

9. S.A. Wright, Critical Energy LLC, 12224 Papaya Ct. NE, Albuquerque, NM, 87111-6255 